\title{
Influence of chemistry on the pyroelectric effect in tourmaline
}

\author{
Kate D. Hawkins* \\ Centre for Microscopy and Microanalysis, University of Queensland, Brisbane, Queensland 4072, Australia; \\ and School of Mechanical and Manufacturing Engineering, Queensland University of Technology, \\ P.O. Box 2434, Brisbane, Queensland 4001, Australia \\ IAN D. R. MacKinNon \\ Centre for Microscopy and Microanalysis, University of Queensland, Brisbane, Queensland 4072, Australia \\ Helmut SChNeEberger** \\ Institut für Kristallographie und Mineralogie, Ludwig-Maximilians-Universität, Theresienstraße 41, Munich, Germany
}

\begin{abstract}
Pyroelectric coefficients were measured from a series of natural tourmaline crystals between $\sim 170$ and $\sim 500 \mathrm{~K}$ to quantify the variation of the pyroelectric effect with chemical composition. The amount of $\mathrm{Fe}$ in tourmaline has a prominent influence on the pyroelectricity. Fe content linearly decreases the pyroelectric coefficient in the composition range between $0.01(1)$ and $14.6(2) \mathrm{wt} \% \mathrm{FeO}$. Thus, to a first approximation, tourmaline pyroelectric coefficients may be predicted directly from the chemical composition derived by routine electron probe microanalysis.

The relationships between pyroelectricity and chemistry indicate that the pyroelectric coefficient is influenced to different extents by the occupancies of the $\mathrm{X}, \mathrm{Y}$, and $\mathrm{Z}$ cation sites in the tourmaline structure. The octahedral $Y$ site occupancy strongly influences the pyroelectric coefficient due to the preference of Fe for this site. This work further suggests that the addition of $\mathrm{Fe}$ and $\mathrm{Mg}$ cations to the smaller $\mathrm{Z}$ octahedral site causes the pyroelectric coefficient to increase. However, because an extended suite of samples is not available in which the $\mathrm{Z}$ site contains ions other than $\mathrm{Al}$, this proposed trend has not been experimentally determined. The chemistry of the ninefold coordinated $X$ site and the population of this site do not influence the pyroelectric coefficients of tourmaline.
\end{abstract}

\section{INTRODUCTION}

Tourmalines are naturally occurring minerals with the general formula $\mathrm{XY}_{3} \mathrm{Z}_{6}\left(\mathrm{BO}_{3}\right)_{3} \mathrm{Si}_{6} \mathrm{O}_{18}(\mathrm{O}, \mathrm{OH}, \mathrm{F})_{4}$, where usually $\mathrm{X}=\mathrm{Na}, \mathrm{Ca}$, or a vacancy, $\mathrm{Y}=\mathrm{Al}, \mathrm{Li}, \mathrm{Fe}^{2+}, \mathrm{Fe}^{3+}$, and many other cations, and $\mathrm{Z}=\mathrm{Al}, \mathrm{Mg}$, and $\mathrm{Fe}^{3+}$. It has been known for centuries (Dietrich, 1985) that tourmaline crystals are pyroelectric materials that develop an electrostatic charge when heated or cooled. Careful measurements of the combined primary and secondary pyroelectric effects in these minerals were first reported by Ackermann (1915). The results of that work showed that tourmaline exhibits pyroelectricity over a wide temperature range. Tourmaline is stable to high temperatures and may find application as an infrared detector where ferroelectric materials such as $\mathrm{LaTiO}_{3}$ fail (Hamid, 1980). Importantly, Ackermann's (1915) measurements show that differently colored tourmalines exhibit different degrees of pyroelectricity. For example, black varieties are the weakest whereas rose colored tourmalines are the most

\footnotetext{
* Present address: CSIRO Division of Minerals, P.O. Box 124, Port Melbourne, Victoria 3207, Australia.

** Present address: Bahnhofstraße 10a, 86551 Aichach, Germany.

$0003-004 X / 95 / 0506-0491 \$ 02.00$
}

strongly pyroelectric. Subsequent investigations support these observations and show that tourmaline pyroelectric coefficients $\left(p_{3}^{o}\right)$ range between $\sim 1.8$ and $5.4 \mu \mathrm{C} /\left(\mathrm{m}^{2} \cdot \mathrm{K}\right)$ at $296 \mathrm{~K}$ (Hayashi, 1912; Röntgen, 1914; Ackermann, 1915; Gladkii and Zheludev, 1965; Gavrilova, 1965; Fabel and Henish, 1971; Drozhdin et al., 1975; Gavrilova et al. 1989; the present work). Related studies have shown that piezoelectricity, the inducement of an electric charge by an applied stress, is also stronger in translucent colored tourmalines than in certain opaque black varieties (Cady, 1946).

None of these previous studies has addressed the variation in the pyroelectric coefficients with either the precise chemical composition or crystal chemistry of differently colored tourmalines. Tourmaline crystal chemistry is complex because the size and anion coordination of the $\mathrm{X}, \mathrm{Y}$, and $\mathrm{Z}$ cation sites are different. As a result, many different cations can be accommodated in tourmaline by coupled isomorphous substitution (e.g., Henry and Guidotti, 1985; Foit et al., 1989; Burt, 1989). An indication of this complexity is given by the summary of natural and synthetic tourmaline end-members as well as by the references to their structural descriptions in $\mathrm{Ta}$ ble 1 . 
TABLE 1. Tourmaline end-member compositions

\begin{tabular}{|c|c|c|c|c|c|}
\hline End-member & $x$ & $Y$ & $z$ & First description & Refined structure \\
\hline \multicolumn{6}{|c|}{ Natural end-members } \\
\hline $\begin{array}{l}\text { Buergerite } \\
\text { Chromdravite } \\
\text { Dravite } \\
\text { Elbaite } \\
\text { Feruvite } \\
\text { Liddicoatite } \\
\text { Povondraite* } \\
\text { Schorl } \\
\text { Tsilaisite*^ } \\
\text { Uvite }\end{array}$ & $\begin{array}{l}\mathrm{Na} \\
\mathrm{Na} \\
\mathrm{Na} \\
\mathrm{Na} \\
\mathrm{Ca} \\
\mathrm{Ca} \\
\mathrm{Na} \\
\mathrm{Na} \\
\mathrm{Na} \\
\mathrm{Ca}\end{array}$ & $\begin{array}{l}\mathrm{Fe}_{3}^{3+} \\
\mathrm{Mg}_{3} \\
\mathrm{Mg}_{3} \\
(\mathrm{Al}, \mathrm{Li})_{3} \\
\mathrm{Fe}_{3}^{2+} \\
(\mathrm{Al}, \mathrm{Li})_{3} \\
\mathrm{Fe}_{3}^{3+} \\
\mathrm{Fe}_{3}^{2+} \\
(\mathrm{Mn}, \mathrm{Al})_{3} \\
\mathrm{Mg}{ }_{3}\end{array}$ & $\begin{array}{l}\mathrm{Al}_{6} \\
\left(\mathrm{Cr}_{5} \mathrm{Al}\right) \\
\mathrm{Al}_{6} \\
\mathrm{Al}_{6} \\
(\mathrm{Al}, \mathrm{Mg})_{6} \\
\mathrm{Al}_{6} \\
\mathrm{Fe}_{6}^{3+} \\
\mathrm{Al}_{6} \\
\mathrm{Al}_{6} \\
\left(\mathrm{Al}{ }_{5} \mathrm{Mg}\right)\end{array}$ & $\begin{array}{l}\text { Mason et al. (1964) } \\
\text { Rumantseva (1983) } \\
\text { Tschermak (1885) } \\
\text { Vernadsky (1913) } \\
\text { Grice and Robinson (1989) } \\
\text { Dunn et al. (1977) } \\
\text { Walenta and Dunn (1979) } \\
\text { Mathesius (1564) } \\
\text { Schmetzer and Bank (1984) } \\
\text { Dunn (1977) }\end{array}$ & $\begin{array}{l}\text { Barton (1969) } \\
\text { Nuber and Schmetzer (1979) } \\
\text { Buerger et al. (1962) } \\
\text { Donnay and Barton (1972) } \\
\text { n.d. } \\
\text { Nuber and Schmetzer (1981) } \\
\text { Grice et al. (1993) } \\
\text { Fortier and Donnay (1975) } \\
\text { Nuber and Schmetzer (1984) } \\
\text { Schmetzer et al. (1979) }\end{array}$ \\
\hline \multicolumn{6}{|c|}{ Synthetic end-members } \\
\hline \multirow{2}{*}{$\begin{array}{l}\text { Alkali-defect dravite } \\
\text { "Sodium aluminum" } \\
\text { tourmaline† }\end{array}$} & - & $\left(\mathrm{Mg}_{2} \mathrm{Al}\right)$ & $\mathrm{Al}_{6}$ & Rosenberg and Foit (1979) & Rosenberg and Foit (1979) \\
\hline & $\mathrm{Na}$ & $\mathrm{Al}_{3}$ & $\mathbf{A I}_{6}$ & Rosenberg et al. (1986) & Rosenberg et al. (1986) \\
\hline \multicolumn{6}{|c|}{$\begin{array}{l}\text { Note: n.d. = not determined. } \\
\text { " Povondraite was initially termed "ferridravite" (Walenta and Dunn, } 1 \\
\text { rystal structure refinement (Grice et al., 1993). } \\
{ }^{*} \text { Tsilaisite = manganoan elbaite. } \\
\text { † Also called aluminobuergerite (Foit, 1975) and olenite (Burt, 1989). }\end{array}$} \\
\hline
\end{tabular}

Primary pyroelectricity describes the development of an electric voltage at the poles of certain noncentrosymmetric crystals, such as tourmaline (space group $R 3 \mathrm{~m}$ ), as temperature is changed. A permanent electric dipole or spontaneous polarization is inherent along the $\langle 00 . l\rangle$ axis in tourmaline. As temperature is varied, the charge distribution in the structure shifts to produce a voltage along this axis. This voltage dissipates as atmospheric molecules are adsorbed onto the surface, so the crystal soon reverts to electrical neutrality.

The primary pyroelectric coefficient is a vector property, isolated when the external electric field, applied stress, and applied strain on a crystal are constant or zero (Nye, 1957). However, thermal expansion in a crystal held under such conditions establishes a strain field. Thus, a component of the measured pyroelectric coefficient is caused by the piezoelectric effect. This component, known as secondary pyroelectricity, is important for this work, as it produces between 75 and $90 \%$ of the observed pyroelectric effect in tourmaline (Zheludev, 1971; Bhalla and Cross, 1981; Lang, 1974). It is impractical to prevent thermal expansion of a crystal by mechanical clamping. Thus, pyroelectric coefficients of tourmaline are measured parallel to the $\langle 00 . l\rangle$ directions and the $d_{33}$ piezoelectric tensor from unclamped crystals at constant stress $(\sigma)$. The measured pyroelectric coefficient $\left(p_{3}^{o}\right)$ is the sum of these primary and secondary coefficients.

A nonuniform strain field caused by a temperature gradient produces tertiary pyroelectricity (Nye, 1957). This effect produces erratic data. Therefore, tertiary pyroelectricity must be avoided by maintaining uniform heat distribution in the material during experimental determination of pyroelectric coefficients.

For this study, relationships between pyroelectricity and the chemistry of tourmaline are investigated for selected samples from $\sim 170$ to $\sim 500 \mathrm{~K}$. From these data, the effects of chemical composition on the $p_{3}^{\sigma}$ variation in tourmalines are determined. These data complement previous studies, which correlated the crystal chemistry of tourmalines with other material properties such as color and refractive indices (e.g., Rossman et al., 1991; Deer et al., 1992) and magnetic and mechanical properties (e.g., Donnay et al., 1967; Tsang et al., 1971; Dobrovol'skaya and Kuz'min, 1975; Helme and King, 1978; Tatli, 1980, 1985; Tatli and Özkan, 1987).

\section{EXPERIMENTAL METHODS}

\section{Preparation of single-crystal plates}

Pyroelectric coefficients were obtained from singlecrystal tourmaline plates with normals parallel to the $\langle 00 . l\rangle$ crystallographic directions. Crystals detailed in Table 2 were aligned by back-reflection Laué diffractographs. The diffractographs showed the error in alignment, $\theta<0.5^{\circ}$. This tolerance produces a $0.004 \%$ error between the measured pyroelectric coefficient $\left(p_{3}^{\sigma}\right)$ and the true coefficient $\left(p_{3}^{\sigma}\right)$ of the plate, by the following equation:

$$
\frac{p_{3}^{\sigma}-p_{3}^{\sigma^{\prime}}}{p_{3}^{\sigma}}=(1-\cos \theta) .
$$

This equation is derived from Figure 1, which schematically illustrates the relationship between coefficient vectors and a plate surface. Plates $\sim 300$ and $900 \mu \mathrm{m}$ thick were sliced from the crystal and then polished with flatness and parallelism within a $\pm 10-\mu \mathrm{m}$ tolerance (Hawkins, 1993).

Translucent polished plates were examined with the petrographic microscope to select crystal volumes suitable for pyroelectric measurement. Material with cracks or color zoning was rejected. Regions with uniaxial conoscopic images were cut from these larger plates to form test plates for pyroelectric measurements, since biaxial fringes are evidence for internal strain or chemical zoning 
TABLE 2. Tourmaline mineral samples

\begin{tabular}{llll}
\hline \hline Sample & $\begin{array}{l}\text { Color and }(\langle 00 . I) \text { axis } \\
\text { length, basal dia) }(\mathrm{cm})\end{array}$ & \multicolumn{1}{c}{ Provenance } & Museum catalogue no. \\
\hline S1b & dark green $(3.5,0.5)$ & Maine, U.S.A. & S.K. Dobos \\
S3a & black $(3.0,0.9)$ & Harts Range, Australia & S.K. Dobos \\
S8 & green-blue $(1.0,0.7)$ & Minas Gerais, Brazil & Daddow's Rock Shop \\
S19 & black $(0.5,2.0)$ & Ratnapura, Sri Lanka & Smithsonian B14657 \\
S21 & black $(3.8,1.4)$ & Pakistan & QGRS \\
S32 & dark green $(2.5,1.0)$ & Brazil & Harvard H\#91844 \\
S33a & black $(1.2,0.9)$ & Rollstone Hill, U.S.A. & Harvard (no cat. no.) \\
S35 & dark blue $(1.5,0.7)$ & Hindu Kush, Afghanistan & AMNH 41859 \\
S36 & pale aqua $(1.5,1.3)$ & Plumbago Mine, U.S.A. & AMNH 40730 \\
S37 & dark blue $(1.5,1.0)$ & Usakos, Namibia & AMNH 24116 \\
S40 & mauve $(1.0,2.5)$ & Plumbago Mine, U.S.A. & AMNH 40732 \\
S41 & black $(1.0,3.5)$ & Tourmaline Queen, U.S.A. & AMNH 46244 \\
S42 & dark olive $(0.5,5.0)$ & Madagascar & Gemological Inst \\
S43 & pale green $(2.0,0.5)$ & Himalaya Mine, U.S.A. & Gemological Inst \\
S49 & black $(3.0,1.0)$ & Black Jack, Australia & Australian D14988 \\
S50 & black $(5 . t, 1.5)$ & unknown & D.J. Henry \\
\hline
\end{tabular}

Note: tourmaline samples were loaned and donated from the following sources: S.K. Dobos, Department of Earth Sciences, University of Queensland, Brisbane, Australia; Daddow's Rock Shop, Stanley Street, Woolloongabba, Brisbane, Queensland, Australia; Quality Gem Rough Supplies (QGRS), P.O. Box 129, Kyneton, Victoria, Australia; D.J. Henry, Department of Geology and Geophysics, Louisiana State University, Baton Rouge, Louisiana 70803-4101, U.S.A.; Harvard University Mineralogical Museum, 24 Oxford Street, Cambridge, Massachusetts 02138, U.S.A.; American Museum of Natural History (AMNH), Central Park West at Seventy-ninth Street, New York, New York 10024-5192, U.S.A.; National Museum of Natural History, Smithsonian Institution, Washington, DC 20560, U.S.A.; Gemological Institute, 1660 Stewart Street, Santa Monica, California 90404, U.S.A.; and the Australian Museum, 6-8 College Street, Sydney, New South Wales 2000, Australia.

(Foord and Mills, 1978). These flaws may produce tertiary pyroelectric effects. For plates containing no volumes of uniaxial structure, volumes of low biaxial distortion were selected. Test plates were cut from the opaque schorl without petrographic examination. These schorl samples (S3a, S21, and S49) have highly mosaic structures, as shown by neutron-rocking curves across individual Bragg reflections (Hawkins, 1993).

Surface areas of opaque and densely colored plates were measured from images captured with a Panasonic WVBL600 video-rate CCD camera fitted with a Canon 50 $\mathrm{mm}$ macro lens and extender tube. The captured images were analyzed with the MD30-plus Image Analysis System on an IBM-PC 386. Conversely, the S36 plate did not provide sufficient contrast for image analysis. The surface area for this plate was obtained from its density measured by heavy liquids and its thickness and mass.

\section{Pyroelectric coefficient measurement}

Pyroelectric coefficients were measured by an electronic circuit (Schneeberger, 1992) built after Byer and Roundy (1972). A Au film electrode was evaporated onto both faces of each plate of surface area $A$ and then mounted on a heating element and cooled to $\sim 170 \mathrm{~K}$. The temperature was increased at a constant rate $(\mathrm{d} T / \mathrm{d} t)$ between \pm 2 and $\pm 6 \mathrm{~K} / \mathrm{min}$ to $500 \mathrm{~K}$ and then decreased at a constant rate. The varying pyroelectric current $(I)$ measured at 100 points during each increasing and decreasing temperature ramp was used to calculate the pyroelectric coefficient at each temperature, $p_{3}^{\sigma}(T)$, by the following equation (Byer and Roundy, 1972):

$$
p_{3}^{\sigma}(T)=\frac{I}{\mathrm{~A}(\mathrm{~d} T / \mathrm{d} t)}
$$

The measurements were repeated for each plate with dif- ferent heating rates. At least two plates from each tourmaline specimen were measured to check for reproducibility.

\section{Electron probe microanalysis and structural formulae}

The tourmaline plates were coated with a $200 \AA \mathrm{C}$ film. Chemical analyses were collected using a JEOL JXA$8800 \mathrm{~L}$ automated electron microprobe with four wavelength dispersive spectrometers. Thirteen elements were calibrated against the following primary standards: $\mathrm{SiO}_{2}$, spessartine garnet; $\mathrm{TiO}_{2}, \mathrm{TiO}_{2}, \mathrm{Al}_{2} \mathrm{O}_{3}$, spessartine garnet; $\mathrm{Cr}_{2} \mathrm{O}_{3}$, chromite; $\mathrm{FeO}$, hematite; $\mathrm{MnO}$, spessartine garnet; $\mathrm{NiO}$, synthetic $\mathrm{Ni}_{2} \mathrm{SO}_{4} ; \mathrm{ZnO}, \mathrm{ZnS} ; \mathrm{MgO}, \mathrm{MgO} ; \mathrm{CaO}$, wollastonite; $\mathrm{Na}_{2} \mathrm{O}$, albite; $\mathrm{K}_{2} \mathrm{O}$, orthoclase; $\mathrm{F}, \mathrm{MgF}_{2}$. Secondary standards were analyzed prior to each session.

Line scans were made approximately normal to each other across each plate with a $15-\mathrm{kV}, 15-\mathrm{nA}$ beam. Analyses were taken at 100 or $200 \mu \mathrm{m}$ intervals. These intervals are broad compared with the fine, 1-3 $\mu \mathrm{m}$ zonation features in some tourmalines (e.g., Grice and Robinson, 1989; Cavarretta and Puxeddu, 1990; Henry and Du-

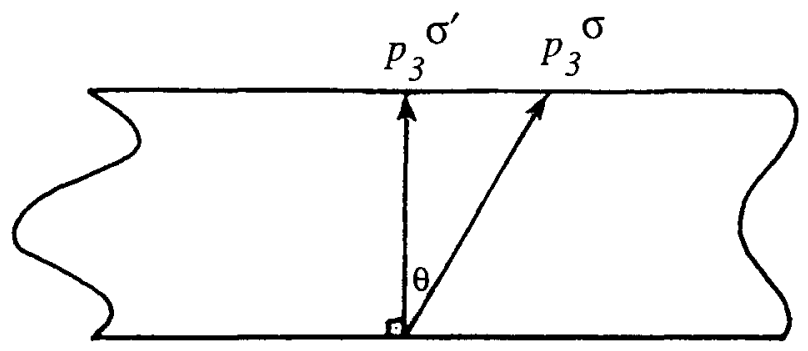

Fig. 1. Geometric relationship between the true $\left(p_{3}^{\sigma}\right)$ and measured $\left(p_{3}^{\sigma^{\prime}}\right)$ pyroelectric coefficients and the surface of a crystal plate. 
TABLE 3. Average compositions and structural formulae of the pyroelectric test plates

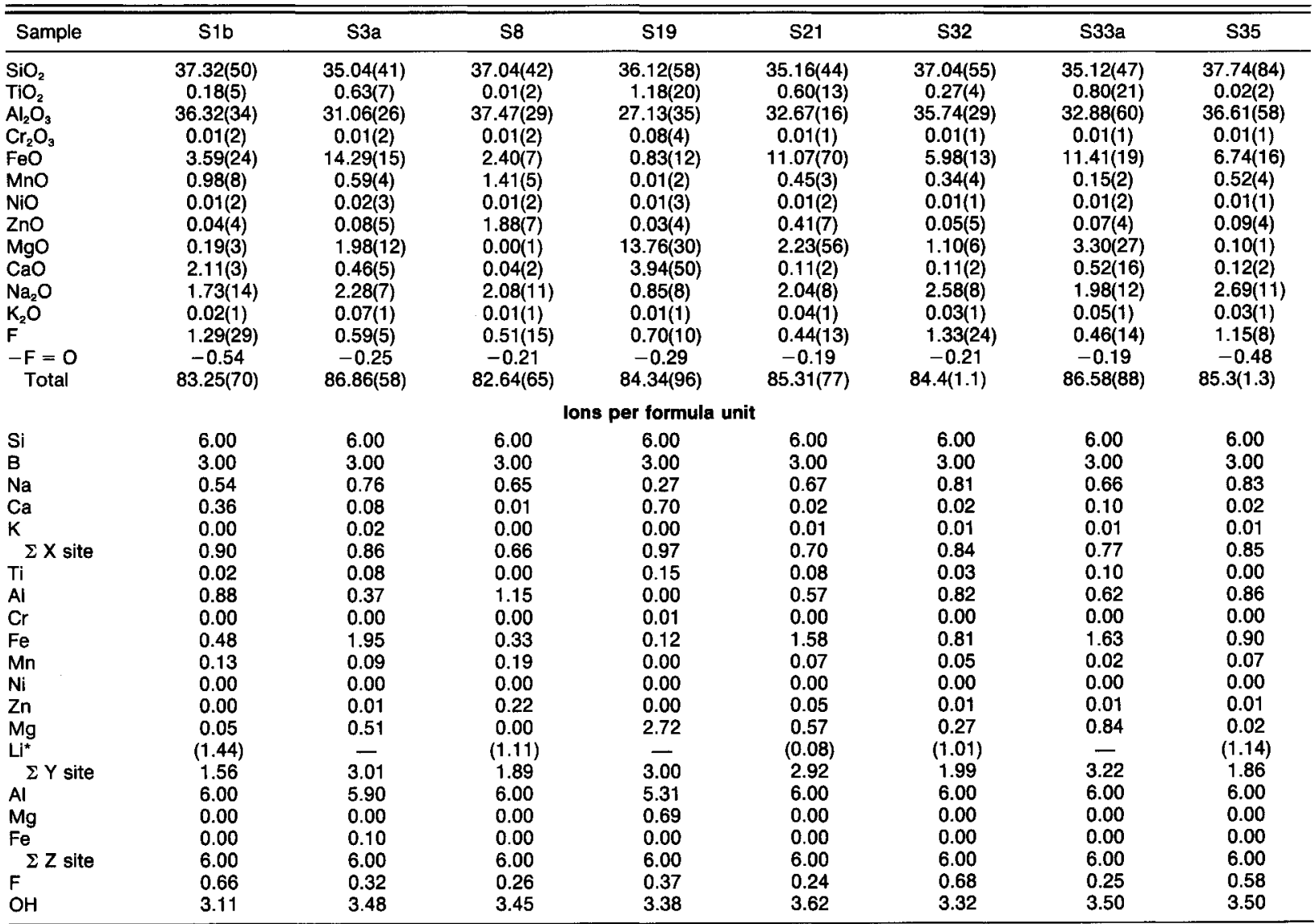

Note: n.a. = not analyzed. Values in parentheses are 1 esd of the microprobe traverse analyses.

" $L i$ ions pfu are the difference from full $Y$ site occupancy.

trow, 1992). The intervals used in this work allowed each plate to be investigated within the constraints of instrument time, yet gave sufficient data to obtain an average composition with estimated standard deviations (esd) representative of chemical variation across the plates.

Structural formulae were normalized to six $\mathrm{Si}$ atoms per formula unit. The assumptions for cation site assignments are similar to those summarized by Rosenberg and Foit (1979). B is assumed to be present in stoichiometric amounts. $\mathrm{Na}, \mathrm{Ca}$, and $\mathrm{K}$ are assigned to the ${ }^{[9]} \mathrm{X}$ site. Multivalent cations are assumed to be in the oxidation states $\mathrm{Fe}^{2+}, \mathrm{Mn}^{2+}$, and $\mathrm{Ti}^{4+} . \mathrm{Al}$ is assigned to the smaller ${ }^{[6]} \mathrm{Z}$ site and excess $\mathrm{Al}$ is assigned to the larger ${ }^{[6]} \mathrm{Y}$ site. All remaining cations are assigned to the $Y$ site. If there is a deficiency of $\mathrm{Al}$, the smaller cations such as $\mathrm{Mg}$ and excess $\mathrm{Fe}^{2+}$ (in lieu of $\mathrm{Fe}^{3+}$ ) are assigned to the $\mathrm{Z}$ site, using crystal ion radii (Shannon, 1976) as a guide. No attempt is made to partition the same ion between both octahedral sites. An exception is the S3a schorl in which $\mathrm{Fe}$ is partitioned between the $\mathrm{Y}$ and $\mathrm{Z}$ sites, using the ratio derived from Mössbauer studies and refined during single-crystal $\mathrm{X}$-ray structure determination (Hawkins, 1993).
Some $Y$ site vacancies are present when these criteria are followed. However, structural refinement has shown that $\mathrm{Y}$ site vacancies are unlikely in tourmaline (Donnay and Barton, 1972; Foit and Rosenberg, 1977; Rosenberg and Foit, 1979; Hawkins, 1993). Therefore, Y site vacancies are filled by $\mathrm{Li}$ if the mineral has a lithia-rich provenance, i.e., if it contains elbaite or liddicoatite components. The number of $\mathrm{H}$ ions is estimated from bond valence sums (Brese and O'Keeffe, 1991).

\section{RESULTS}

\section{Test plate quality}

Chemical variation within the tourmaline test plates may affect their suitability for electrical measurements. Thus, two statistical tests were applied to the sets of traverse analyses to assess (1) whether there is chemical zonation within the plates and (2) whether two or more plates from the same crystal have the same average chemistry.

First, the variation in concentrations along a traverse was compared with the counting statistics for each element. For this study, microprobe traverses do not show zoning at a $95 \%$ confidence level if the relative variation 
TABLE 3.-Continued

\begin{tabular}{|c|c|c|c|c|c|c|c|c|}
\hline Sample & S36 & S37 & $S 40$ & S41 & $\mathrm{S} 42$ & $\$ 43$ & $\$ 49$ & S50 \\
\hline \begin{tabular}{l}
$\mathrm{SiO}_{2}$ \\
$\mathrm{TiO}_{2}$ \\
$\mathrm{Al}_{2} \mathrm{O}_{3}$ \\
$\mathrm{Cr}_{2} \mathrm{O}_{3}$ \\
$\mathrm{FeO}$ \\
$\mathrm{MnO}$ \\
$\mathrm{NiO}$ \\
$\mathrm{ZnO}$ \\
$\mathrm{MgO}$ \\
$\mathrm{CaO}$ \\
$\mathrm{Na}_{2} \mathrm{O}$ \\
$\mathrm{K}_{2} \mathrm{O}$ \\
$\mathrm{F}$ \\
$-\mathrm{F}=\mathrm{O}$ \\
\multicolumn{2}{c}{ Total }
\end{tabular} & $\begin{array}{c}38.83(26) \\
0.01(1) \\
38.32(23) \\
0.01(1) \\
2.13(21) \\
0.57(5) \\
0.01(1) \\
0.13(3) \\
0.02(1) \\
0.52(8) \\
2.18(5) \\
0.02(1) \\
0.92(6) \\
-0.39 \\
83.29(47)\end{array}$ & $\begin{array}{c}37.68(33) \\
0.01(2) \\
36.98(38) \\
0.01(2) \\
4.84(22) \\
0.80(5) \\
0.01(2) \\
0.27(10) \\
0.03(2) \\
0.32(3) \\
2.59(7) \\
0.02(1) \\
1.13(7) \\
-0.47 \\
84.21(60)\end{array}$ & $\begin{array}{c}39.45(76) \\
0.01(1) \\
40.39(26) \\
0.01(2) \\
0.01(1) \\
0.18(4) \\
0.01(2) \\
0.02(4) \\
0.00(1) \\
0.49(5) \\
1.65(11) \\
0.01(1) \\
\text { n.a. } \\
-\overline{82.2(1.2)}\end{array}$ & $\begin{array}{c}34.7(1.0) \\
0.03(4) \\
35.77(25) \\
0.01(2) \\
8.84(18) \\
1.72(8) \\
0.01(3) \\
0.89(15) \\
0.05(2) \\
0.03(2) \\
1.93(9) \\
0.03(2) \\
0.49(16) \\
-0.21 \\
84.3(1.0)\end{array}$ & $\begin{array}{c}37.87(61) \\
0.07(4) \\
38.36(63) \\
0.01(2) \\
2.29(14) \\
0.34(6) \\
0.01(3) \\
0.06(7) \\
0.03(2) \\
0.44(13) \\
2.13(10) \\
0.02(2) \\
0.87(24) \\
-0.37 \\
82.1(1.0)\end{array}$ & $\begin{array}{c}38.18(15) \\
0.03(2) \\
38.61(24) \\
0.01(1) \\
0.79(6) \\
0.77(4) \\
0.01(2) \\
0.05(4) \\
0.01(1) \\
1.48(8) \\
1.69(4) \\
0.01(1) \\
1.10(6) \\
-0.46 \\
82.27(32)\end{array}$ & $\begin{array}{c}35.39(80) \\
0.41(23) \\
33.2(1.0) \\
0.01(2) \\
14.04(94) \\
0.16(5) \\
0.01(2) \\
0.07(8) \\
0.63(11) \\
0.10(6) \\
1.77(20) \\
0.04(2) \\
0.46(20) \\
-0.43 \\
86.1(1.4)\end{array}$ & $\begin{array}{c}36.91(48) \\
0.02(2) \\
35.49(56) \\
0.01(3) \\
8.32(22) \\
0.31(4) \\
0.01(2) \\
0.20(6) \\
0.11(2) \\
0.06(2) \\
2.66(9) \\
0.03(1) \\
1.60(28) \\
-0.67 \\
85.05(73)\end{array}$ \\
\hline \multicolumn{9}{|c|}{ Ions per formula unit } \\
\hline $\begin{array}{l}\mathrm{Si} \\
\mathrm{B} \\
\mathrm{Na} \\
\mathrm{Ca} \\
\mathrm{K} \\
\mathrm{\Sigma} \times \text { site } \\
\mathrm{Ti} \\
\mathrm{Al} \\
\mathrm{Cr} \\
\mathrm{Fe} \\
\mathrm{Mn} \\
\mathrm{Ni} \\
\mathrm{Zn} \\
\mathrm{Mg} \\
\mathrm{Li} \\
\quad \mathrm{Y} \text { site } \\
\mathrm{Al} \\
\mathrm{Mg} \\
\mathrm{Fe} \\
\mathrm{\Sigma} \mathrm{Z} \text { site } \\
\mathrm{F} \\
\mathrm{OH}\end{array}$ & $\begin{array}{c}6.00 \\
3.00 \\
0.65 \\
0.09 \\
0.00 \\
0.74 \\
0.00 \\
0.98 \\
0.00 \\
0.28 \\
0.07 \\
0.00 \\
0.01 \\
0.00 \\
(1.66) \\
1.34 \\
6.00 \\
0.00 \\
0.00 \\
6.00 \\
0.45 \\
3.40\end{array}$ & $\begin{array}{c}6.00 \\
3.00 \\
0.80 \\
0.05 \\
0.00 \\
0.85 \\
0.00 \\
0.94 \\
0.00 \\
0.64 \\
0.11 \\
0.00 \\
0.03 \\
0.01 \\
(1.28) \\
1.72 \\
6.00 \\
0.00 \\
0.00 \\
6.00 \\
0.57 \\
3.53\end{array}$ & $\begin{array}{c}6.00 \\
3.00 \\
0.49 \\
0.08 \\
0.00 \\
0.57 \\
0.00 \\
1.24 \\
0.00 \\
0.00 \\
0.02 \\
0.00 \\
0.00 \\
0.00 \\
(1.74) \\
1.26 \\
6.00 \\
0.00 \\
0.00 \\
6.00 \\
\text { n.a. } \\
3.88-\mathrm{F}\end{array}$ & $\begin{array}{c}6.00 \\
3.00 \\
0.65 \\
0.01 \\
0.01 \\
0.67 \\
0.00 \\
1.28 \\
0.00 \\
1.28 \\
0.25 \\
0.00 \\
0.11 \\
0.01 \\
(0.08) \\
2.92 \\
6.00 \\
0.00 \\
0.00 \\
6.00 \\
0.27 \\
3.62\end{array}$ & $\begin{array}{l}6.00 \\
3.00 \\
0.65 \\
0.07 \\
0.00 \\
0.72 \\
0.01 \\
1.16 \\
0.00 \\
0.30 \\
0.05 \\
0.00 \\
0.01 \\
0.01 \\
(1.46) \\
1.54 \\
6.00 \\
0.00 \\
0.00 \\
6.00 \\
0.44 \\
3.38\end{array}$ & $\begin{array}{l}6.00 \\
3.00 \\
0.51 \\
0.25 \\
0.00 \\
0.76 \\
0.00 \\
1.15 \\
0.00 \\
0.10 \\
0.10 \\
0.00 \\
0.01 \\
0.00 \\
(1.64) \\
1.36 \\
6.00 \\
0.00 \\
0.00 \\
6.00 \\
0.55 \\
3.31\end{array}$ & $\begin{array}{l}6.00 \\
3.00 \\
0.58 \\
0.02 \\
0.01 \\
0.61 \\
0.05 \\
0.64 \\
0.00 \\
1.99 \\
0.02 \\
0.00 \\
0.01 \\
0.16 \\
(0.13) \\
2.87 \\
6.00 \\
0.00 \\
0.00 \\
6.00 \\
0.25 \\
3.62\end{array}$ & $\begin{array}{c}6.00 \\
3.00 \\
0.84 \\
0.01 \\
0.01 \\
0.86 \\
0.00 \\
0.80 \\
0.00 \\
1.13 \\
0.04 \\
0.00 \\
0.02 \\
0.03 \\
(0.98) \\
2.02 \\
6.00 \\
0.00 \\
0.00 \\
6.00 \\
0.82 \\
3.22\end{array}$ \\
\hline
\end{tabular}

in concentration for each element does not exceed twice the relative variation in counting statistics. By this criterion, all plates except $\mathrm{S} 40$ and S43 showed zoning in some elements.

Second, differences between the average chemical compositions of plates cut from the same tourmaline specimen were determined for each element within a $95 \%$ confidence interval by a Student $t$-test (Walpole and Myers, 1978). In most cases, the compositions of all elements were consistent between plates. Thus, the analyses shown in Table 3 are the averages of microprobe traverses within these confidence limits for each sample.

\section{Pyroelectricity vs. temperature curves}

In this temperature range, the pyroelectric response for tourmaline is a convex curve, as illustrated in Figure 2. Curves for the repeated temperature cycles and for several plates from the same crystal were fitted with a quadratic function. The error in $p_{3}^{\sigma}$ shown in Table 4 is calculated from the spread of the data from the fitted function (Schneeberger, 1992). In most cases, plates from the same specimen gave the same curve within these error margins. Thus, the dimensional tolerances, chemical zonation, and flaws in these tourmaline plates were ac- ceptable for reproducible measurement of $p_{3}^{\sigma}$. Repeat data collected from the same crystal were added to form the quadratic functions for $p_{3}^{\sigma}$ vs. $T$ given in Table 4 . The $S 1 b$ and S41 samples are exceptions to the reproducibility generally observed within samples. The two S1b samples gave consistently different intersecting curves, as shown by the equations in Table 4 . An explanation for these differences is not obvious because both plates are of similar quality. Thus, $\mathrm{S} 1 \mathrm{~b}$ results are omitted from further analysis. Similarly, one $\$ 41$ plate was omitted from the average curve for this sample because it produced pyroelectric coefficients that were consistently $\sim 10 \%$ higher than those for three other S41 plates. This difference may be attributed to inaccurate surface-area measurement of one plate.

The low-temperature form of the pyroelectric response curve is shown in Figure 2. The lowest temperature obtained in this work was limited by the liquid $\mathrm{N}_{2}$ coolant, and so the polarity inversion in tourmaline $p_{3}^{a}$ at $<20 \mathrm{~K}$ (e.g., Drozhdin et al., 1975; Gavrilova et al., 1989) was not detected.

The high-temperature region of the curve adopts one of two forms. First, there is an upward inflection of the curve shown in Figure 2. This behavior has been noted 


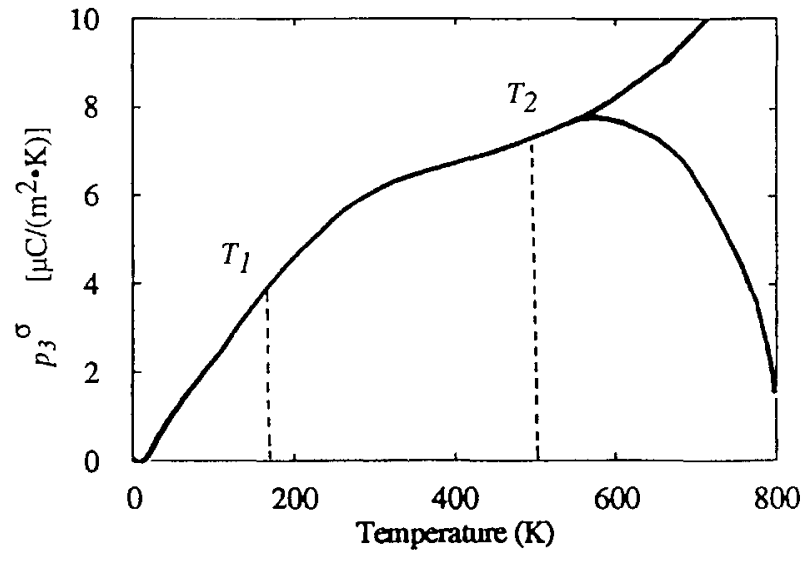

Fig. 2. The general form of the pyroelectric response with temperature change for tourmaline. The approximate temperature range for the present measurements is between $T_{1}$ and $T_{2}$. A low-temperature polarity inversion is shown at $<20 \mathrm{~K}$ (after Gavrilova et al., 1989).

for only a pale rose sample above $450 \mathrm{~K}$ (Ackermann, 1915; Gavrilova et al., 1983, 1989). However, this type of behavior was observed during one experiment of the $\mathrm{S} 1 \mathrm{~b} / 5$ plate above $\sim 420 \mathrm{~K}$ and for both $\mathrm{S} 49$ plates above $\sim 400 \mathrm{~K}$. A similar inflection has been predicted for the thermal expansion vs. temperature relationship in other minerals. For example, strong anharmonic thermal vibration above $1300 \mathrm{~K}$ in forsterite produces an upward inflection of the calculated thermal expansion coefficient curve (Reynard et al., 1992). Thermal expansion causes the secondary pyroelectric effect, which is a strong effect in tourmaline. Thus, this region of the curve in Figure 2 may reflect the effects of anharmonic vibration on pyroelectricity. These results indicate that the onset of pyroelectricity that is caused by anharmonic vibration of ions in the structure and high thermal expansion may occur at a lower temperature in S1b/5 and S49 than in other tourmalines.
Second, a smooth decrease in the pyroelectric coefficient was observed in the schorl S33a plate above $\sim 430$ $\mathrm{K}$. This behavior, which is probably caused by the onset of electrical conductivity, has not been previously reported in tourmaline. Such conductivity is different from the electric current generated in the external circuit from the pyroelectric voltage. This tourmaline is omitted from further analysis because it produced an anomalously low $p_{3}^{\sigma}$. This problem arose from a difficulty in the accurate determination of surface area because of chipped edges.

Further upper temperature limits were encountered with S21, S32, and S41 plates, as shown in Table 4. The signals from these plates contained high levels of electronic noise at higher temperatures.

\section{Pyroelectric coefficient variation with bulk chemistry}

Clearly, tourmaline bulk chemistry determines the pyroelectric response of this mineral. To investigate trends between the pyroelectric coefficients and chemistry, pyroelectric coefficients were calculated from equations for 14 samples in Table 4 at two temperatures. Low-temperature behavior is represented by data at $193 \mathrm{~K}$. Although most samples were measured to $\sim 500 \mathrm{~K}$, some plates gave erratic responses above $\sim 400 \mathrm{~K}$. Therefore, higher temperatures are represented by data at $383 \mathrm{~K}$, so all 14 samples could be included in the data set. The variations in tourmaline pyroelectric coefficients with bulk chemistry are shown by the graphs in Figure 3.

FeO. The linear decrease in pyroelectric coefficient with increase in Fe content (as wt $\% \mathrm{FeO}$ ), shown in Figure 3a, is the most important result. The data at 193 and $383 \mathrm{~K}$ are strongly linear, as the linear least-squares correlation coefficient $r$ is $\sim 0.9$ in both cases. This high correlation is statistically significant, since the random probability for 14 data points with a correlation coefficient between 0.85 and 0.90 is $<0.1 \%$ (Taylor, 1982). The higher temperature data are more strongly linear, and the slope of this line is higher than for the $193 \mathrm{~K}$ data. Thus, an increase in $\mathrm{Fe}$ content has a stronger influence on tourmaline py-

TABLE 4. Empirical equations for the temperature dependence of $p_{3}^{q}$

\begin{tabular}{|c|c|c|c|}
\hline Sample & $p_{3}^{\sigma}\left[\mu \mathrm{C} /\left(\mathrm{m}^{2} \cdot \mathrm{K}\right)\right]$ & Error & $T$ range $(\mathrm{K})$ \\
\hline 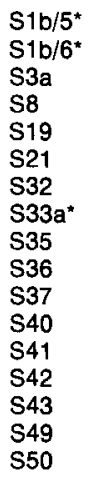 & $\begin{array}{l}-0.2379+1.732 \times 10^{-2} T-9.54 \times 10^{-6} T^{2} \\
4.379 \times 10^{-2}+1.178 \times 10^{-2} T-8.133 \times 10^{-8} T^{2} \\
-0.3686+1.112 \times 10^{-2} T-4.259 \times 10^{-6} T^{2} \\
-0.979+2.194 \times 10^{-2} T-1.873 \times 10^{-5} T^{2} \\
-0.8659+1.97 \times 10^{-2} T-1.652 \times 10^{-5} T^{2} \\
-2.661+2.849 \times 10^{-2} T-3.170 \times 10^{-5} T^{2} \\
-1.588+2.257 \times 10^{-2} T-1.976 \times 10^{-5} T^{2} \\
-0.6975+1.056 \times 10^{-2} T-6.903 \times 10^{-6} T^{2} \\
-1.88+2.308 \times 10^{-2} T-1.976 \times 10^{-5} T^{2} \\
-1.19+2.33 \times 10^{-2} T-1.987 \times 10^{-5} T^{2} \\
-1.310+2.024 \times 10^{-2} T-1.578 \times 10^{-5} T^{2} \\
-0.4096+1.816 \times 10^{-2} T-1.226 \times 10^{-5} T^{2} \\
-0.8918+1.950 \times 10^{-2} T-1.620 \times 10^{-5} T^{2} \\
-0.9894+1.979 \times 10^{-2} T-1.465 \times 10^{-5} T^{2} \\
-0.7167+2.246 \times 10^{-2} T-1.883 \times 10^{-5} T^{2} \\
-0.9472+1.500 \times 10^{-2} T-9.123 \times 10^{-6} T^{2} \\
-1.585+1.954 \times 10^{-2} T-1.566 \times 10^{-5} T^{2}\end{array}$ & $\begin{array}{l}0.10 \\
0.10 \\
0.17 \\
0.07 \\
0.20 \\
0.15 \\
0.22 \\
0.15 \\
0.07 \\
0.11 \\
0.10 \\
0.10 \\
0.16 \\
0.07 \\
0.14 \\
0.10 \\
0.06\end{array}$ & $\begin{array}{l}170-423 \\
170-500 \\
170-500 \\
170-500 \\
170-500 \\
170-463 \\
170-483 \\
170-433 \\
170-500 \\
170-500 \\
170-500 \\
170-500 \\
170-443 \\
170-500 \\
170-500 \\
170-403 \\
170-500\end{array}$ \\
\hline
\end{tabular}

* Pyroelectric equations from these samples are not included in the anlaysis of $\rho_{3}^{*}$ variation with chemistry. 
roelectricity at higher temperature. This effect could be caused by an increase in electrical conduction of Fe-rich tourmaline at elevated temperatures and is consistent with the proposed onset of electrical conductivity in schorl. The $p_{3}^{\alpha}$ may approach a plateau for the Fe-rich tourmalines S3a, S21, and S49, as indicated by the term 'schorl' in Figure 3a. This small invariant region is more evident at low temperature.

$\mathrm{SiO}_{2}$. The $p_{3}^{\sigma}$ variation with $\mathrm{SiO}_{2}$ content is linear, as shown in Figure 3b. However, this variation results from the heavy element content such as $\mathrm{Fe}$, since there is only minor substitution for $\mathrm{Si}$ in tourmaline (e.g., Walenta and Dunn, 1979; Henry and Guidotti, 1985; Gallagher, 1988). An inverse proportionality between weight percent $\mathrm{SiO}_{2}$ and weight percent $\mathrm{FeO}$ is seen by comparison of Figure $3 a$ and $3 b$.

$\mathrm{MnO}_{2}$. A weak linear relationship between $p_{3}^{\sigma}$ and weight percent $\mathrm{MnO}_{2}$ is shown in Figure 3c.

$\mathbf{A l}_{2} \mathbf{O}_{3}$. There are two regions denoted by 1 and 2 in circles in Figure 3d. In the Al-rich region (1), $p_{3}^{\sigma}$ increases with $\mathrm{Al}_{2} \mathrm{O}_{3}$ concentration. This region is detailed in Figure $3 \mathrm{e}$. A minimum $p_{3}^{\sigma}$ value corresponding to the schorl samples S3a, S21, and $\mathrm{S} 49$ identified in the $\mathrm{FeO}$ relationship in Figure 3a occurs around 31-33 wt $\mathrm{Al}_{2} \mathrm{O}_{3}$. The data in this minimum region fit the linear relationship shown in Figure 3e without degrading the correlation coefficient. Therefore, the data points at this minimum are included in region 1. However, $r$ may appear artificially high because the data set is small. With further depletion of $\mathrm{Al}$ from tourmaline, the pyroelectric coefficient increases again (Fig. 3d, region 2). The data point shown near $27 \mathrm{wt} \% \mathrm{Al}_{2} \mathrm{O}_{3}$ represents the $\mathrm{S} 19$ uvite-dravite, supporting the data in Figure $3 \mathrm{f}$ and indicating that incorporation of large amounts of $\mathrm{Mg}$ in the tourmaline lattice increases $p_{3}^{\sigma}$.

MgO. There is a discontinuity in data between $\sim 3 \mathrm{wt} \%$ $\mathrm{MgO}$ and the $\mathrm{S} 19$ uvite-dravite at $14 \mathrm{wt} \% \mathrm{MgO}$ in Figure 3f. At $\mathrm{MgO}$ concentrations below the sharp inflection around $0.10-0.50 \mathrm{wt} \% \mathrm{MgO}$, the relationship between $p_{3}^{\sigma}$ and weight percent $\mathrm{MgO}$ is strongly linear, despite the large composition error bars (Fig. 3g). However, a paucity of suitable dravite or uvite tourmalines prevented detailed investigation of the effect of $\mathrm{Mg}$ incorporation on the pyroelectric coefficients.

$\mathrm{ZnO}, \mathrm{Na}_{2} \mathrm{O}, \mathrm{CaO}$, and $\mathrm{F} . \mathrm{Zn}, \mathrm{F}$, and the $\mathrm{X}$-site cations do not significantly affect the pyroelectric coefficients. $\mathrm{ZnO}$ content vs. $p_{3}^{\sigma}$ displays a very weak inflection around $0.1-$ $0.5 \mathrm{wt} \% \mathrm{ZnO}$ in a trend similar to that of $\mathrm{MgO}$ vs. $p_{3}^{\sigma}$. There is a weak correlation between $\mathrm{Na}_{2} \mathrm{O}$ and $p_{3}^{\mathfrak{a}}$, as shown in Figure 3h.

\section{Discussion}

\section{Pyroelectric coefficients of Fe-containing tourmalines}

These data form a basis for the prediction of tourmaline pyroelectric coefficients directly from electron microprobe $\mathrm{FeO}$ analyses. All tourmaline compositions studied conform to the linear relationship between weight percent $\mathrm{FeO}$ and $p_{3}^{\sigma}$ shown in Figure 3a. Fe-rich tourmalines are


Fig. 3. Relationships between $p_{3}^{\sigma}$ and the bulk chemistry of tourmaline. Error bars are \pm 1 esd for chemical composition (Table 3) and $p_{3}^{\sigma}$ (Table 4). Equations have the form $p_{3}^{\sigma}=\mathrm{A}+\mathrm{B} x$, where $x$ is the weight percent oxide; and $r$ is the correlation coefficient of the linear least-squares fit of the line to the data. (a) $\mathrm{FeO} 193 \mathrm{~K}: \mathrm{A}=2.59, \mathrm{~B}=-0.08, r=-0.86$; $383 \mathrm{~K}$ : $\mathrm{A}=$ 4.79, $\mathrm{B}=-0.10, r=-0.90$. (b) $\mathrm{SiO}_{2} 193 \mathrm{~K}: \mathrm{A}=-4.51, \mathrm{~B}=$ $0.18, r=0.61 ; 383 \mathrm{~K}: \mathrm{A}=-5.91, \mathrm{~B}=0.27, r=0.73$. (c) $\mathrm{MnO}$ $193 \mathrm{~K}: \mathrm{A}=1.99, \mathrm{~B}=0.25, r=0.27 ; 383 \mathrm{~K}: \mathrm{A}=4.02, \mathrm{~B}=$ $0.28, r=0.24$. (d) $\mathrm{Al}_{2} \mathrm{O}_{3}$. (e) $\mathrm{Al}_{2} \mathrm{O}_{3} 193 \mathrm{~K}: \mathrm{A}=-2.99, \mathrm{~B}=0.14$, $r=0.83 ; 383 \mathrm{~K}: \mathrm{A}=-2.94, \mathrm{~B}=0.20, r=0.90$. (f) $\mathrm{MgO}$. (g) $\mathrm{MgO} 193 \mathrm{~K}: \mathrm{A}=2.65, \mathrm{~B}=-9.14, r=-0.88 ; 383 \mathrm{~K}: \mathrm{A}=4.81$, $\mathbf{B}=-9.92, r=-0.86$. (h) $\mathrm{Na}_{2} \mathrm{O} 193 \mathrm{~K}: \mathrm{A}=2.94, \mathrm{~B}=-0.39$, $r=-0.44 ; 383 \mathrm{~K}: \mathrm{A}=4.84, \mathrm{~B}=-0.31, r=-0.28$.

often shown in this study to be black or darkly colored. Thus, this relationship supports the general observation (e.g., Dietrich, 1985) that black tourmalines exhibit weaker pyroelectric behavior than pale colored tourmalines. However, the S19 uvite-dravite is Fe-poor and has a cor- 
TABLE 5. Predicted pyroelectric coefficients $p_{3}^{a}\left[\mu \mathrm{C} /\left(\mathrm{m}^{2} \cdot \mathrm{K}\right)\right]$ and errors for selected tourmaline end-member compositions

\begin{tabular}{|c|c|c|c|c|}
\hline $\begin{array}{l}\text { End- } \\
\text { member }\end{array}$ & $\begin{array}{c}p_{3}^{g} \text { at } \\
193 \mathrm{~K} \\
\text { (Fig. 4) }\end{array}$ & $\begin{array}{c}p_{3}^{\sigma} \\
\text { at } 193 \mathrm{~K} \\
\text { (Eq. 3) }\end{array}$ & $\begin{array}{c}p_{3}^{\sigma} \\
\text { at } 296 \mathrm{~K} \\
\text { (Eq. 4) }\end{array}$ & $\begin{array}{c}p_{3}^{g} \\
\text { at } 383 \mathrm{~K} \\
\text { (Eq. } 5 \text { ) }\end{array}$ \\
\hline $\begin{array}{l}\text { Tourmaline }(\mathrm{FeO}=0 \%) \\
\text { Schorl }(\mathrm{FeO}=20.46 \%)\end{array}$ & - & $\begin{array}{l}2.59(0.50) \\
1.02(0.56)\end{array}$ & $\begin{array}{l}3.95(0.51) \\
2.03(0.57)\end{array}$ & $\begin{array}{l}4.79(0.52) \\
2.68(0.58)\end{array}$ \\
\hline \multicolumn{5}{|c|}{ Fe-free tourmalines } \\
\hline $\begin{array}{l}\text { Uvite } \\
\text { Elbaite } \\
\text { Aluminobuergerite }\end{array}$ & $\begin{array}{l}2.45 \\
3.08 \\
5.75\end{array}$ & $\frac{-}{-}$ & - & - \\
\hline
\end{tabular}

respondingly high $p_{3}^{\sigma}$ value, despite the dark brown or black color. Therefore, these results confirm that color, which has been used previously to characterize tourmalines, is not as reliable as chemistry for the prediction of the pyroelectric coefficients.

Predictive equations between the $p_{3}^{\alpha}$ and FeO content at three temperatures were devised by simple regression analysis, with weight percent oxide as the independent variable and $p_{3}^{\sigma}$ as the dependent variable. These equations include the following:

at $193 \mathrm{~K} \quad p_{3}^{o}=2.594-0.077(\mathrm{wt} \% \mathrm{FeO})$

$$
\mu \mathrm{C} /\left(\mathrm{m}^{2} \cdot \mathrm{K}\right)
$$

at $296 \mathrm{~K} \quad p_{3}^{\mathrm{s}}=3.949-0.094(\mathrm{wt} \% \mathrm{FeO})$

$$
\mu \mathrm{C} /\left(\mathrm{m}^{2} \cdot \mathrm{K}\right)
$$

at $383 \mathrm{~K} \quad p_{3}^{a}=4.791-0.103(\mathrm{wt} \% \mathrm{FeO})$

$$
\mu \mathrm{C} /\left(\mathrm{m}^{2} \cdot \mathrm{K}\right) \text {. }
$$

Pyroelectric coefficients and errors calculated at 193, 296 , and $383 \mathrm{~K}$ for an ideal schorl end-member containing $20.46 \%$ FeO (Dietrich, 1985) and a tourmaline with $\mathrm{FeO}=0 \%$ are listed in Table 5. Pyroelectric coefficients predicted for tourmalines at $296 \mathrm{~K}$ are in good agreement with values for similar samples reported at ambient temperature. For example the $p_{3}^{\sigma}$ value of $2.03(57) \mu \mathrm{C} /\left(\mathrm{m}^{2}\right.$. K) at $296 \mathrm{~K}$ for the schorl agrees extremely well with the value of $2.2 \mu \mathrm{C} /\left(\mathrm{m}^{2} \cdot \mathrm{K}\right)$ for a black tourmaline (Gladkii and Zheludev, 1965). This black tourmaline is probably close to a schorl in composition. Further, the $p_{3}^{\sigma}$ of 4.4 $\mu \mathrm{C} /\left(\mathrm{m}^{2} \cdot \mathrm{K}\right)$ at ambient temperature reported for pink tourmalines (Hayashi, 1912; Ackermann, 1915) is within the error of the value $3.95(51) \mu \mathrm{C} /\left(\mathrm{m}^{2} \cdot \mathrm{K}\right)$ at $296 \mathrm{~K}$ predicted for Fe-free tourmaline. Pink tourmaline is usually an elbaite with minor $\mathrm{Mn}$ substitution.

The errors in $p_{3}^{a}$ predicted from Equations 3-5 are calculated as a $90 \%$ confidence interval based on a Student $t$-test (Walpole and Myers, 1978). These intervals are large percentage errors in $p_{3}^{\sigma}$. Such errors may be reduced only by increasing the number of samples in the data set. However, it is very difficult to obtain tourmaline crystals of the quality required for this measurement technique. For

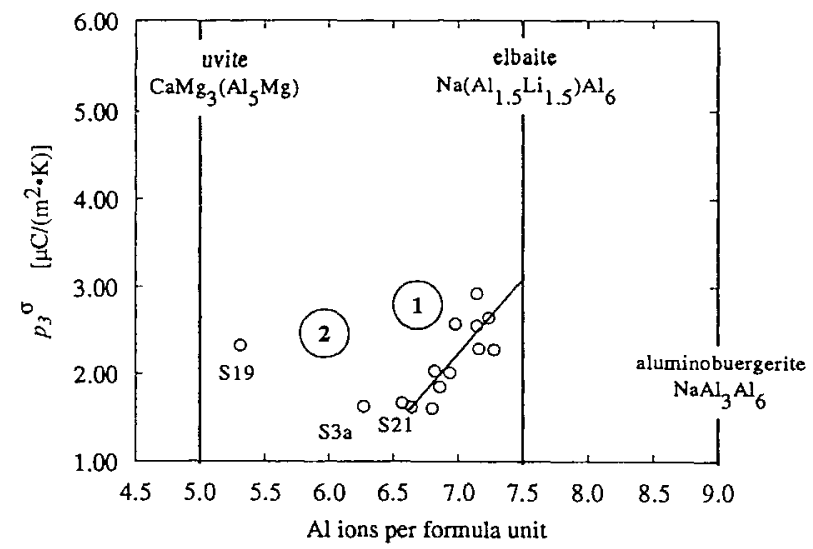

Fig. 4. The number of $\mathrm{Al}$ ions per tourmaline formula unit vs. $p_{3}^{o}$ at $193 \mathrm{~K}$.

example, the 14 samples used in this analysis represent only $27 \%$ of the tourmaline crystals collected for this work (Hawkins, 1993).

It is surprising that the correlation between weight percent $\mathrm{FeO}$ and $p_{3}^{\sigma}$ is so high, despite the assumption that $\mathrm{Fe}$ is divalent for all tourmaline and that the effects of $\mathrm{Fe}$ partitioning between the $\mathrm{Y}$ and $\mathrm{Z}$ sites have not been taken into account.

The strong effect of $\mathrm{FeO}$ concentration may obscure the effects of other ions on $p_{3}^{\sigma}$. Thus, an investigation of the complex crystal chemical substitutions in tourmaline is used to show the dependence of the pyroelectric response on such ions.

\section{Cation substitution effects on the pyroelectric coefficient}

$\mathrm{Y}$ site. The relationship between the number of $\mathrm{Al}$ ions per formula unit (pfu) and $p_{3}^{g}$ is shown in Figure 4. Above $6.5 \mathrm{Al}$ ions in region $1, p_{3}^{\sigma}$ increases with Fe removal by the schorl-elbaite substitution on the $Y$ crystallographic site: $2 \mathrm{Fe}_{\mathbf{Y}}^{2+} \rightleftharpoons \mathrm{Li}_{\mathbf{Y}}^{+}+\mathrm{Al}_{\mathbf{Y}}^{3+}$. This substitution corresponds to the dependence of $p_{3}^{\sigma}$ on weight percent FeO. Therefore, the schorl-elbaite substitution is probably the dominant mechanism for Fe removal to produce high $p_{3}^{\sigma}$ coefficients in Al-rich tourmalines. In these tourmalines, $\mathrm{Z}$ is usually fully occupied by $\mathrm{Al}$.

A similar linear increase in $p_{3}^{o}$ with increased Mn suggests that $\mathrm{Fe}$ is also removed by the $\mathrm{Y}$ site cation substitution: $\mathrm{Fe}_{\mathrm{Y}}^{2+} \rightleftharpoons \mathrm{Mn}_{\mathrm{Y}}^{2+}$. However, this cation exchange is not important for all tourmaline compositions studied, since the amount of $\mathrm{Mn}$ incorporated by this substitution is small, $<2 \mathrm{wt} \% \mathrm{MnO}$. Further, the relationship is weak, as the linear-fit correlation coefficients for data at 193 and $383 \mathrm{~K}$ are $\sim 0.25$, as shown in Figure $3 \mathrm{c}$. At high $\mathrm{Mg}$ concentrations the $\mathrm{Fe}_{\mathrm{Y}}^{2+} \rightleftharpoons \mathrm{Mg}_{\mathrm{Y}}^{2+}$ substitutions deplete $\mathrm{Fe}$ from the structure. The $p_{3}^{\alpha}$ value then increases, as shown in Figure 3f.

Around the minimum inflection of the weight percent $\mathrm{Al}_{2} \mathrm{O}_{3}$ vs. $p_{3}^{\sigma}$ relationship in Figure $4, \mathrm{Fe}$ removal from the $\mathrm{Y}$ site and substitutions for $\mathrm{Al}$ on the $\mathrm{Z}$ site occur 
The effect of $\mathrm{Al}$ content on $p_{3}^{\sigma}$ is probably a result of the substitution of $\mathrm{Al}$ for $\mathrm{Y}$ and $\mathrm{Z}$ site cations, particularly $\mathrm{Fe}$. However, there may be properties of $\mathrm{Al}, \mathrm{Fe}$, and other ions that affect polarity in the structure and pyroelectric behavior.

$\mathbf{Z}$ and $\mathbf{X}$ sites. The regions in Figure 4 that are low and intermediate in $\mathrm{Al}$ content, shown as region 2, indicate that a further set of cation substitutions may affect the $p_{3}^{\sigma}$ values in these tourmalines. A line cannot be drawn from these data because there are insufficient data points. Thus, the data from samples S19, S3a, and S21 (labeled) are discussed individually. The low $\mathrm{Al}$ content of these tourmalines suggests that there are other cations on the $\mathrm{Z}$ site. For example, the $\mathrm{S} 19$ uvite-dravite structural formula (given in Table 3) is depleted in Al. Thus, $0.69 \mathrm{Mg}$ ions and $5.31 \mathrm{Al}$ ions are incorporated in the $\mathrm{Z}$ site by the uvite substitution $\mathrm{Na}_{\mathrm{X}}^{+}+\mathrm{Al}_{\mathrm{Z}}^{++} \rightleftharpoons \mathrm{Ca}_{\mathrm{Y}}^{2+}+\mathrm{Mg}_{\mathrm{Z}}^{2+}$. Powder electron-spin resonance data collected at $\sim 130 \mathrm{~K}$ (Hawkins, 1993) indicate that there is also minor $\mathrm{Fe}^{3+}$ on the $Z$ site of $S 19$. In addition, the $S 3 a$ schorl has been shown by Mössbauer studies and population parameter refinement during least-squares structure analysis (Hawkins, 1993) to contain $0.10 \mathrm{Fe}$ ions per six $\mathrm{Z}$ sites. This analysis suggests that a $13 \%$ substitution of $\mathrm{Mg}$ for $\mathrm{Al}$ and a $1.7 \%$ substitution of $\mathrm{Fe}$ for $\mathrm{Al}$ on the $\mathrm{Z}$ site in the S19 uvite-dravite and S3a schorl, respectively, may strongly increase the pyroelectric coefficient. Other ions, for example Mn (Johnston and Duncan, 1975), partition to the tourmaline $Z$ site. Thus, there are many possible $\mathrm{Z}$ site substitutions for $\mathrm{Al}$ that may affect $p_{3}^{\sigma}$.

\section{Pyroelectric coefficients for Fe-free tourmaline}

There are several Fe-free end-members shown in Table 1. Pyroelectric coefficients of the elbaite $\left[\mathrm{XY}_{3} \mathrm{Z}_{6}=\right.$ $\left.\mathrm{Na}\left(\mathrm{Al}_{1.5} \mathrm{Li}_{1.5}\right) \mathrm{Al}_{6}\right]$, uvite $\left[\mathrm{CaMg}_{3}\left(\mathrm{Al}_{5} \mathrm{Mg}\right)\right]$, and aluminobuergerite $\left(\mathrm{NaAl}_{3} \mathrm{Al}_{6}\right)$ end-members are shown by extrapolation in Figures 4 and 5 . There are sufficient data for the schorl-elbaite substitution series in Figure 4 to extrapolate a value of $p_{3}^{\sigma}$ for elbaite, which is included in the summary of $p_{3}^{\sigma}$ values in Table 5. Similarly, the $p_{3}^{\sigma}$ for uvite is extrapolated in region 2 of Figure 5, although there are fewer data points than in region 1 . It may be difficult to obtain samples in this composition range with further work because there is a miscibility gap reported in the $\mathrm{Al}-\mathrm{Mg}$ (elbaite-dravite) phase field for natural tourmalines (e.g., Donnay and Barton, 1972; Taylor and Slack, 1984; Henry and Guidotti, 1985; Cavarretta and Puxeddu, 1990; Kassoli-Fournaraki, 1990).

The prediction of aluminobuergerite pyroelectric behavior from Figure 4 is justified only if the same linear trend continues from the schorl-elbaite region to higher Al compositions. It may be difficult to explore this relationship further using the present pyroelectric apparatus because large crystals are required. Aluminobuergerite is a synthetic end-member (Foit, 1975) produced when $\mathrm{Al}$ content on the $\mathrm{Y}$ site is increased by the liddicoatite, aluminobuergerite, and olenite substitutions (Henry and Guidotti, 1985; Burt, 1989). Only crystals $<1 \mathrm{~mm}$ in size

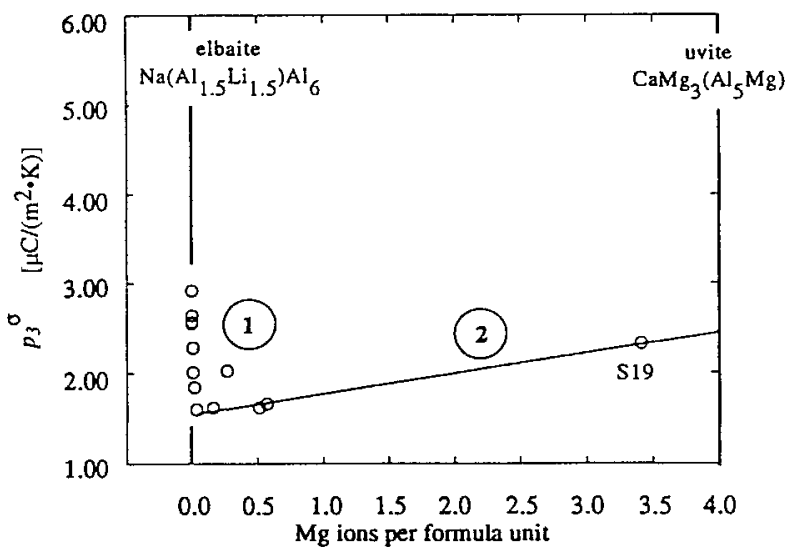

Fig. 5. The number of $\mathrm{Mg}$ ions per tourmaline formula unit vs. $p_{3}^{\sigma}$ at $193 \mathrm{~K}$.

are produced by hydrothermal synthesis (e.g., Taylor and Terrell, 1967; Foit, 1975; Vorbach, 1989).

\section{ACKNOWLEDGMENTS}

This study could not have been completed without many beautiful tourmaline specimens that were made available by colleagues and friends. Steve Dobos and Darrell Henry kindly donated tourmalines from their own mineral collections. The curators of the Harvard University Mineralogical Museum, American Museum of Natural History, National Museum of Natural History (Smithsonian Institution), the Gemological Institute, and the Australian Museum kindly loaned crystals of fine quality for this work. We (K.D.H. and H.S.) thank L. Bohaty of the LudwigMaximilians-Universität (now at Universität Köln, Germany), and S. Haussühl of Universität Köln for many helpful discussions. Thanks to H. Schmid, Université de Genève, Switzerland, for helpful discussions that alerted us (K.D.H.) to potential problems with biaxial crystals for pyroelectric measurement. The Australian Institute for Nuclear Science and Engineering (AINSE) supported K.D.H. by means of a postgraduate studentship.

\section{REFERENCES CITED}

Ackermann, W. (1915) Beobachtungen über Pyroelektrizität in ihrer Abhängigkeit von der Temperatur. Annalen der Physik, 46, 197-220.

Barton, R., Jr. (1969) Refinement of the crystal structure of buergerite and the absolute orientation of tourmalines. Acta Crystallographica, B25, 1524-1533.

Bhalla, A.S., and Cross, L.E. (1981) Primary and secondary pyroelectricity in proper and improper ferroelectrics. Ferroelectrics, 38, 935-938.

Brese, N.E., and O'Keeffe, M. (1991) Bond-valence parameters for solids. Acta Crystallographica, B47, 192-197.

Buerger, M.J., Burnham, C.W., and Peacor, D.R. (1962) Assessment of the several structures proposed for tourmaline. Acta Crystallographica, $15,583-590$.

Burt, D.M. (1989) Vector representation of tourmaline compositions. American Mineralogist, 74, 826-839.

Byer, R.L., and Roundy, C.B. (1972) Pyroelectric coefficient direct measurement technique and application to a NSEC response time detector. Ferroelectrics, 3, 333-338.

Cady, W.G. (1946) Piezoelectricity, 806 p. McGraw-Hill, New York

Cavarretta, G.C., and Puxeddu, M. (1990) Schorl-dravite-ferridravite tourmalines deposited by hydrothermal magmatic fluids during early evolution of the Larderello geothermal field, Italy. Economic Geology, $85,1236-1251$.

Deer, W.A., Howie, R.A., and Zussman, J. (1992) An introduction to the rock-forming minerals (2nd edition), 528 p. Longman, London.

Dietrich, R.V. (1985) The tourmaline group, 300 p. Van Nostrand Reinhold, New York. 
Dobrovol'skaya, N.V., and Kuz'min, V.I. (1975) Magnetic properties of tourmaline. Konstitutsiya i Svoistva Mineralov, 9, 124-130 (in Russian).

Donnay, G. and Barton, R., Jr. (1972) Refinement of the crystal structure of elbaite and the mechanism of tourmaline solid solution. Tschermaks Mineralogische-Petrographische Mitteilungen, 18, 273-286.

Donnay, G., Senftle, F.E., Thorpe, A., and White, S. (1967) Magnetic properties of tourmaline. Carnegie Institution of Washington Year Book, 65, 295-299.

Drozhdin, S.N., Novik, V.K., Koptsik, V.A., and Kobyakov, I.B. (1975) Pyroelectric properties of tourmaline and cancrinite crystals in a wide range of temperatures. Soviet Physics, Solid State, 16, 2122-2123.

Dunn, P.J. (1977) Uvite, a newly classified gem tourmaline. Journal of Gemmology, 15, 300-307.

Dunn, P.J., Appleman, D.E., and Nelen, J.E. (1977) Liddicoatite, a new calcium end-member of the tourmaline group. American Mineralogist, 62, 1121-1124.

Fabel, G.W., and Henisch, H.K. (1971) Technique for the measurement of pyroelectric coefficients. Solid-State Electronics, 14, 1281-1283.

Foit, F.F., Jr. (1975) Aluminobuergerite, $\mathrm{Na}_{1-x} \mathrm{Al}_{3} \mathrm{Al}_{6} \mathrm{~B}_{3} \mathrm{Si}_{6} \mathrm{O}_{27} \mathrm{O}_{3-x}(\mathrm{OH})_{1+\infty}$ a new end-member of the tourmaline group. Eos, 56, 461.

Foit, F.F., Jr., and Rosenberg, P.E. (1977) Coupled substitutions in the tourmaline group. Contributions to Mineralogy and Petrology, 62, 109127.

Foit, F.F., Jr., Fuchs, Y., and Myers, P.E. (1989) Chemistry of alkalideficient schorls from two tourmaline-dumortierite deposits. American Mineralogist, 74, 1317-1324.

Foord, E.E., and Mills, B.A. (1978) Biaxiality in 'isometric' and 'dimetric' crystals. American Mineralogist, 63, 316-325.

Fortier, S., and Donnay, G. (1975) Schorl refinement showing composition dependence of the tourmaline structure. Canadian Mineralogist, 13, 173-177

Gallagher, V. (1988) Coupled substitutions in schorl-dravite tourmaline: New evidence from SE Ireland. Mineralogical Magazine, 52, 637-650.

Gavrilova, N.D. (1965) Temperature dependence of pyroelectric coefficients as studied by a static method. Kritallografiya, 10, 346-350.

Gavrilova, N.D., Drozhdin, S.N., Novik, V.K., and Maksimov, E.G. (1983) Relationship between the pyroelectric coefficient and the lattice dynamics of the pyroelectrics. Solid State Communications, 48, 129-133.

Gavrilova, N.D., Maksimov, E.G., Novik, V.K, and Drozhdin, S.N. (1989) The low-temperature behavior of the pyroelectric coefficient. Ferroelectrics, 100, 223-240.

Gladkii, V.V., and Zheludev, I.S. (1965) Method and results of studying the pyroelectric properties of certain single crystals. Soviet PhysicsCrystallography, 10, 50-53.

Grice, J.D., and Robinson, G.W. (1989) Feruvite, a new member of the tourmaline group and its crystal structure. Canadian Mineralogist, 27, 199-203.

Grice, J.D., Ercit, T.S., and Hawthorne, F.C. (1993) Povondraite, a redefinition of the tourmaline ferridravite. American Mineralogist, 78, 433-436.

Hamid, S.A. (1980) Tourmaline as a pyroelectric infra-red radiation detector. Zeitschrift für Kristallographie, 151, 67-75.

Hawkins, K.D. (1993) Crystal chemical and structural analysis of pyroelectricity in tourmaline, 292 p. Ph.D. thesis, University of Queensland, Brisbane, Queensland, Australia

Hayashi, F. (1912) Observations of pyroelectricity, 48 p. Thesis, Göttingen, Germany.

Helme, B.G., and King, P.J. (1978) The elastic constants of iron tourmaline (schörl). Journal of Material Science, 13, 1487-1489.

Henry, D.J., and Dutrow, B.L. (1992) Tourmaline in a low grade clastic metasedimentary rock: An example of the petrographic potential of tourmaline. Contributions to Mineralogy and Petrology, 112, 203-218.

Henry, D.J., and Guidotti, C.V. (1985) Tourmaline as a petrogenetic indicator mineral: An example from the staurolite-grade metapelites of NW Maine. American Mineralogist, 70, 1-15.

Johnston, J.H., and Duncan, J.F. (1975) Manganese ion site distribution studies in tourmaline by anomalous $X$-ray scattering methods. Journal of Applied Crystallography, 8, 469-472.

Kassoli-Foumaraki, A. (1990) Chemical variations in tourmalines from pegmatite occurrences in Chalkidiki Peninsula, Northern Greece.
Schweizerische Mineralogische und Petrographische Mitteilungen, 70, 55-65.

Lang, S.B. (1974) Sourcebook of pyroelectricity, 375 p. Gordon and Breach, London.

Mason, B., Donnay, G., and Hardie, L.A. (1964) Ferric tourmaline from Mexico. Science, 144, 71-73.

Mathesius, J. (1564) Sarepta oder Bergpostill: Sampt der Jochimstalischen Kurtschen Chroniken. Reprint, Návroni Technické Muzeum Praha, Prague, 1975.

Nuber, B., and Schmetzer, K. (1979) Die Gitterposition des $\mathrm{Cr}^{3+}$ im Turmalin: Strukturverfeinerung eines $\mathrm{Cr}$-reichen $\mathrm{Mg}$-Al-Turmalins. Neues Jahrbuch für Mineralogie Abhandlungen, 137, 184-197.

(1981) Strukturverfeinerung von Liddicoatit. Neues Jahrbuch für Mineralogie Monatshefte, 5, 215-219.

-(1984) Structural refinement of tsilaisite (manganese tourmaline). Neues Jahrbuch für Mineralogie Monatshefte, 7, 301-304.

Nye, J.F. (1957) Physical properties of crystals: Their representation by tensors and matrices, 322 p. Clarendon, Oxford, U.K.

Reynard, B., Price, G.D., and Gillet, P. (1992) Thermodynamic and anharmonic properties of forsterite, $\alpha-\mathrm{Mg}_{2} \mathrm{SiO}_{4}$ : Computer modeling versus high-pressure and high-temperature measurements. Journal of Geophysical Research, 97, 19791-19802.

Röntgen, W.C. (1914) Pyro- and piezoelectric investigations. Annalen der Physik, 45, 737-800.

Rosenberg, P.E., and Foit, F.F., Jr. (1979) Synthesis and characterization of alkali-free tourmaline. American Mineralogist, 64, 180-186.

Rosenberg, P.E., Foit, F.F., Jr., and Ekambaram, V. (1986) Synthesis and characterization of tourmaline in the system $\mathrm{Na}_{2} \mathrm{O}-\mathrm{Al}_{2} \mathrm{O}_{3}-\mathrm{SiO}_{2}-\mathrm{B}_{2} \mathrm{O}_{3}$ $\mathrm{H}_{2}$ O. American Mineralogist, 71, 971-976.

Rossman, G.R., Fritsch, E., and Shigley, J.E. (1991) Origin of color in cuprian elbaite from São José de Batalha, Paraíba, Brazil. American Mineralogist, 76, 1479-1484.

Rumantseva, E.V. (1983) Chromdravite, a new mineral. Zapiski Vsesoyuznogo Mineralogicheskogo Obshchestva, 112, 222-226.

Schmetzer, K., and Bank, H. (1984) Crystal chemistry of tsilaisite (manganese tourmaline) from Zambia. Neues Jahrbuch für Mineralogie Monatshefte, 2, 61-69.

Schmetzer, K., Nuber, B., and Abraham, K. (1979) Zur Kristallchemie Magnesium-reicher Turmaline. Neues Jahrbuch für Mineralogie Abhandlungen, 136, 93-112.

Schneeberger, H. (1992) Pyroelektrische Eigenschaften nicht-ferroelektrischer Kristalle, 246 p. Ph.D. thesis, Ludwig-Maximilians-Universität, Munich, Germany.

Shannon, R.D. (1976) Revised effective ionic radii and systematic studies of interatomic distances in halides and chalcogenides. Acta Crystallographica, A32, 751-767.

Tatli, A. (1980) Ultrasonic investigation of the variation of the elastic properties of tourmalines with structure, composition and temperature, 93 p. Ph.D. thesis, Middle East Technical University, Ankara, Turkey. (1985) Zero-field elastic constants of uvite. Journal of Physics and Chemistry of Solids, 46, 1015-1018.

Tatli, A., and Özkan, H. (1987) Variation of the elastic constants of tourmaline with chemical composition. Physics and Chemistry of Minerals, $14,172-176$

Taylor, A.M., and Terrell, B.C. (1967) Synthetic tourmalines containing elements of the first transition series. Journal of Crystal Growth, 1, 238-244.

Taylor, B.E., and Slack, J.F. (1984) Tourmalines from Appalachian-Caldeonian massive sulfide deposits: Textural, chemical and isotopic relationships. Economic Geology, 79, 1703-1726.

Taylor, J.R. (1982) An introduction to error analysis, 270 p. University Science Books, Mill Valley, California.

Tsang, T., Thorpe, A.N., Donnay, G., and Senftle, F.E. (1971) Magnetic susceptibility and triangular exchange coupling in the tourmaline mineral group. Journal of Physics and Chemistry of Solids, 32, 1441-1448.

Tschermak, G. (1885) Lehrbuch der Mineralogie, 682 p. Hölder, Wien, Austria.

Vernadsky, W. (1913) Über die chemische Formel der Turmaline. Zeitschrift für Kristallographie, Kristallogeometri Kristallphysik, Kristallchemie, 53, 273-288.

Vorbach, A. (1989) Experimental examinations on the stability of syn thetic tourmalines in temperatures from $250^{\circ} \mathrm{C}$ to $750^{\circ} \mathrm{C}$ and pres 
sures up to $4 \mathrm{~kb}$. Neues Jahrbuch für Mineralogie Abhandlungen, 161, 69-83.

Walenta, K., and Dunn, P.J. (1979) Ferridravite, a new mineral of the tourmaline group from Bolivia. American Mineralogist, 64, 945-948.

Walpole, R.E., and Myers, R.H. (1978) Probability and statistics for engineers and scientists (2nd edition), 580 p. Macmillan, New York.
Zheludev, I.S. (1971) Physics of crystalline dielectrics. In Crystallography and spontaneous polarization, vol. 1, 336 p. Plenum, New York.

MANuscript ReCeived February 18, 1994

MANUSCRIPT ACCEPTED JANUARY 12, 1995 